\title{
全国のAMeDAS観測点における Degree-Day法および融雪係数の検証 VERIFICATION OF DEGREE-DAY METHOD AND SNOWMELT RATE FACTER IN AMEDAS POINTS OVER JAPAN
}

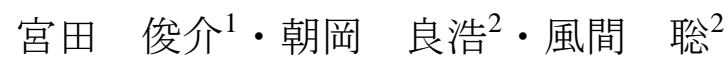 \\ Syunsuke MIYATA, Yoshihiro ASAOKA and So KAZAMA \\ 1学生員 東北大学大学院工学研究科( $7980-8579$ 宮城県仙台市青葉区荒巻字青葉6-6-06) \\ 2正会員 東北大学大学院工学研究科 (广980-8579 宮城県仙台市青葉区荒巻字青葉6-6-06)
}

\begin{abstract}
This paper verificated Degree-Day method, one of the temperature-based snowmelt methods, over Japan with AMeDAS data. Snowmelt rate factor, which is parameter of the Degree-Day method, is optimized comparing observed snowdepth at AMeDAS point with estimated snow depth with SWE model and snow density estimation model. As a result, the optimized Degree-Day factor is able to estimate snowdpth with high accuracy at more than around $86 \%$ AMeDAS points. But snowmodel estimates snowdepth with less than $80 \%$ correlation factor at less than $1 \mathrm{~m}$ maximum snowdepth and high temperature point. Moreover, we confirmed that maximum snowdepth and temperature have effect on snowmelt rate factor. Sensibility of correlation factor against temperature and precipitation showed same results.
\end{abstract}

Key Words : AMeDAS, Degree-Day method, snowmelt rate facter, SWE model

\section{1. はじめに}

日本において，積雪は重要な水資源であるが，地球温 暖化をはじめとする気候変動は, 降雪や積雪, 融雪と いった雪現象に大きな影響を及ぼす，過去の長期的な積 雪量の再現は，気候変動あるいは気候変動が積雪水資源 に与える影響の評価に対して有効なデータといえる.

AMeDAS（地域気象観測システム， Automated Meteorological Data Acquisiton System) は約30年間の観測 データを保有し, 空間解像度はおよそ $17 \mathrm{~km}$ 四方である.

このためAMeDASデータを積雪モデルにインプットする ことにより，過去の長期にわたる積雪量のデータが作成 された1).

積雪モデルは融雪量を推定する融雪モデルを組み込む 必要があるが，融雪モデルは熱収支法とDegree-Day法の 二つに分類することができる，熱収支法は融雪に寄与す るエネルギーを成分ごとに求め，積雪層と大気の熱交換 をモデル化した手法である．エネルギ一交換の原理に基 づいて融雪量を推定できるが，多種多様な気象観測デー タを空間的に高密度で必要とするため，広域に適用する ことは難しい. これに対し，Degree-Day法は積雪期間の
日融雪量が日平均気温と線形関係にあると仮定する手法 である．気温のみで融雪量を推定するシンプルな方法で あり，AMeDASデータを用いた広域にわたる積雪量の推 定に適している. Degree-Day法のパラメータである融雪 係数は気象や地域に応じて設定する必要がある.

日本ではDegree-Day法を適用して広域の積雪量・融雪 量分布を推定した事例が多い2)，3). しかしDegree-Day法 は物理的根拠に乏しい簡易モデルであり，信頼性や適用 性に問題がある. 山崎 ${ }^{4}$ は融雪係数の熱収支的な解釈を 試み，限られた試験地において融雪係数の検証を行った. しかし日本は南北に延び，かつ春梁山脈によって気象が 異なるので，様々な地点においてDegree-Day法の妥当性 について検証する必要がある.

そこで本研究は Degree-Day法を組み込んだ積雪モデ ルを広域に適用した際の精度や適用性を明らかにするこ とを目的とした。この目的のため, AMeDAS観測点約 300か所における過去30年の融雪係数を推定し，積雪深 の推定值と実測值を比較する.これにより日本全域の AMeDAS観測点において積雪モデルの精度を調べ，その 精度の気象依存性を定量的に抽出した. また，積雪モデ ルの融雪係数と気象観測データを解析し, 融雪係数の地 域性に対する物理的な考察を行った. ただし, 融雪係数 


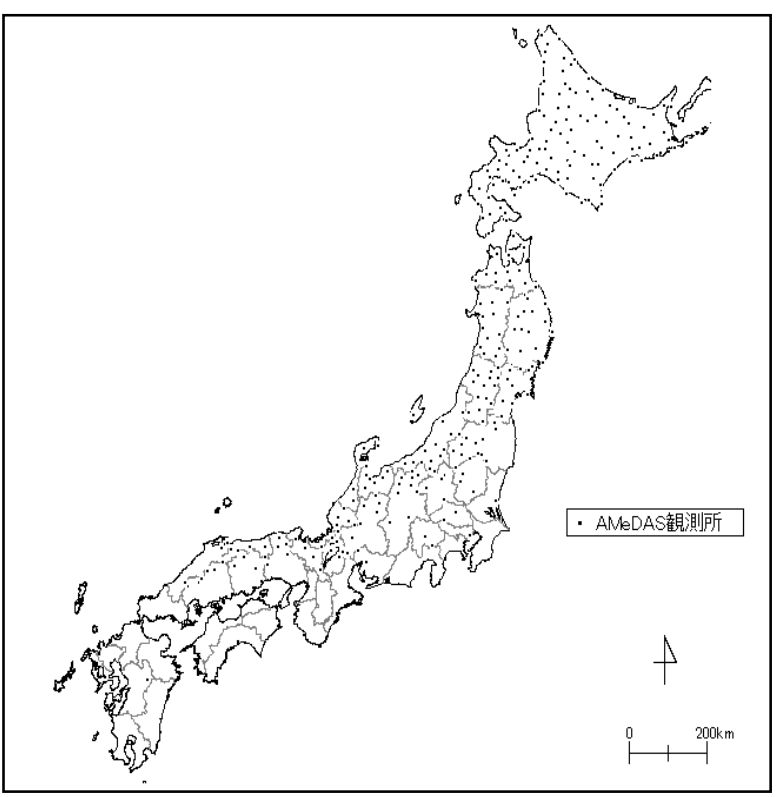

図-1＼cjkstart対象となる AMeDAS 観測点の分布図

の年変動については議論していない，さらに， DegreeDay法の精度を示寸相関係数について感度分析を行い， Degree-Day法の精度に影響を与える気象要素を定量的に 評価した。これらはDegree-Day法やDegree-Day法を用い た積雪モデルの汎用性を高めるための重要なプロセスで あると考えられる。

\section{2. データセット}

風速と降水量，気温，日照時間，積雪深を観測する約 300か所のAMeDAS観測点（図-1）を対象として積雪モ デルを適用した．解析の対象期間は観測開始から2004年 4月までとし，11月から翌年4月までを積雪期間として一 定の融雪係数を求めた．ただし積雪期間中の積雪日数が 15日以上のケースのみを解析の対象ととした. これは積 雪日数が極端に短い場合には，データ数の少なさのため 後述する相関係数が過大評価されることを考慮したため である.

各地点における気象データ (降水量と気温，風速，日 照時間, 積雪深) はアメダス統計值から取得した。

AMeDAS統計值とは全国各地のAMeDAS観測点で得ら れた観測データを，1976年から2004年までの29年間収録 したものである．本論文は日単位の観測データのみを用 いており，以降本論文において，特に断りの無い限り観 測データは日単位のデータを指すものとする.

\section{Degree-Day法を用いた積雪モデル}

\section{（1）Degree-Day法について}

Degree-Day法とは融雪の原因となる諸因子を気温で代 表させる方法である. 融雪量は次式で示される.

$$
S M=T \cdot K
$$

ここで， $S M$ は日融雪量 $(\mathrm{mm} / \mathrm{day}), T$ は日平均気温 $\left({ }^{\circ} \mathrm{C}\right)$, $K$ は融雪係数 $\left(\mathrm{mm} / \mathrm{day} \cdot{ }^{\circ} \mathrm{C}\right)$ である. 融雪係数はDegreeDay法において融雪量を決定する重要なパラメータであ り，日本では $0.7 か ら 8.0 \mathrm{~mm} /{ }^{\circ} \mathrm{C} \cdot$ day程度の值をとること が報告されている5 . 本研究では各AMeDAS観測点の各 積雪期間における融雪係数を推定する.

\section{（2）融雪係数の最適化と積雪モデルの検証}

融雪係数は各アメダス観測点における日最大積雪深の 観測値と，積雪モデルによる日最大積雪深（以降日最大 積雪深を積雪深と記述する）の推定值を同定することに より求める. 融雪係数を 0.1 から 20.0 まで0.1刻みに変化 させ，積雪深の観測值と任意の融雪係数に対応した積雪 深の推定值の相関係数を求め, 相関係数が最大となる融 雪係数を採用する．相関係数により，最適化された融雪 係数によるDegree-Day法を用いた積雪モデルが，積雪深 をどの程度再現可能か定量的に評価できる．また相関係 数と気象データの解析により, 気象要素が積雪モデルの 精度に与える影響について調べる.

\section{（3）積雪モデル}

積雪モデルは，積雪水量モデルと全層積雪密度モデル により構成され，気温と降水量の気象データを入力デー タとして用いる．まず，積雪水量モデルについて説明す る. 積雪水量モデルを用いて積雪水量を推定する式を以 下に示す.

$$
S W E=S W E^{\prime}+S F-S M
$$

ここで $S W E$ は積雪水量 $(\mathrm{mm} / \mathrm{day}), S W E^{\prime}$ は前日の積雪 水量 $(\mathrm{mm} / \mathrm{day}), S F$ は降雪水量 $(\mathrm{mm} / \mathrm{day})$ であり, 表面で 発生した融雪水は即座に積雪層加底面一流出寸ると仮 定して，積雪底面流出量を融雪量とみなしている．また 底面融雪量および降雨による融雪量は考慮していない。 ここで降水形態を判別する必要がある．広域における判

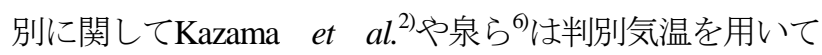
いる. 本研究もこれらに倣い, 日平均気温が $2^{\circ} \mathrm{C}$ 以上の 降水形態を降雨とし， $2^{\circ} \mathrm{C}$ 以下の降水形態を降雪とした。 次に積雪水量から積雪深を推定するために，風間 ${ }^{7} の$ 全層積雪密度推定モデルを用いた。このモデルは広域に 適用可能で一定の精度が得られ，これまでに様々な観測 地点においてその妥当性が確認されてきたの)7，全層積雪 密度は以下の式により示される.

$$
\rho d=\frac{S W E}{S D}+\beta\left(0.55-\rho d^{\prime}\right)
$$

ここで $\rho d$ は全層積雪密度 $\left(\mathrm{g} / \mathrm{cm}^{3}\right), S D$ は積雪深 $(\mathrm{mm})$, $\beta$ は圧密速度, $\rho d^{\prime}$ は前日の全層積雪密度 $\left(\mathrm{g} / \mathrm{cm}^{3}\right)$ である. 

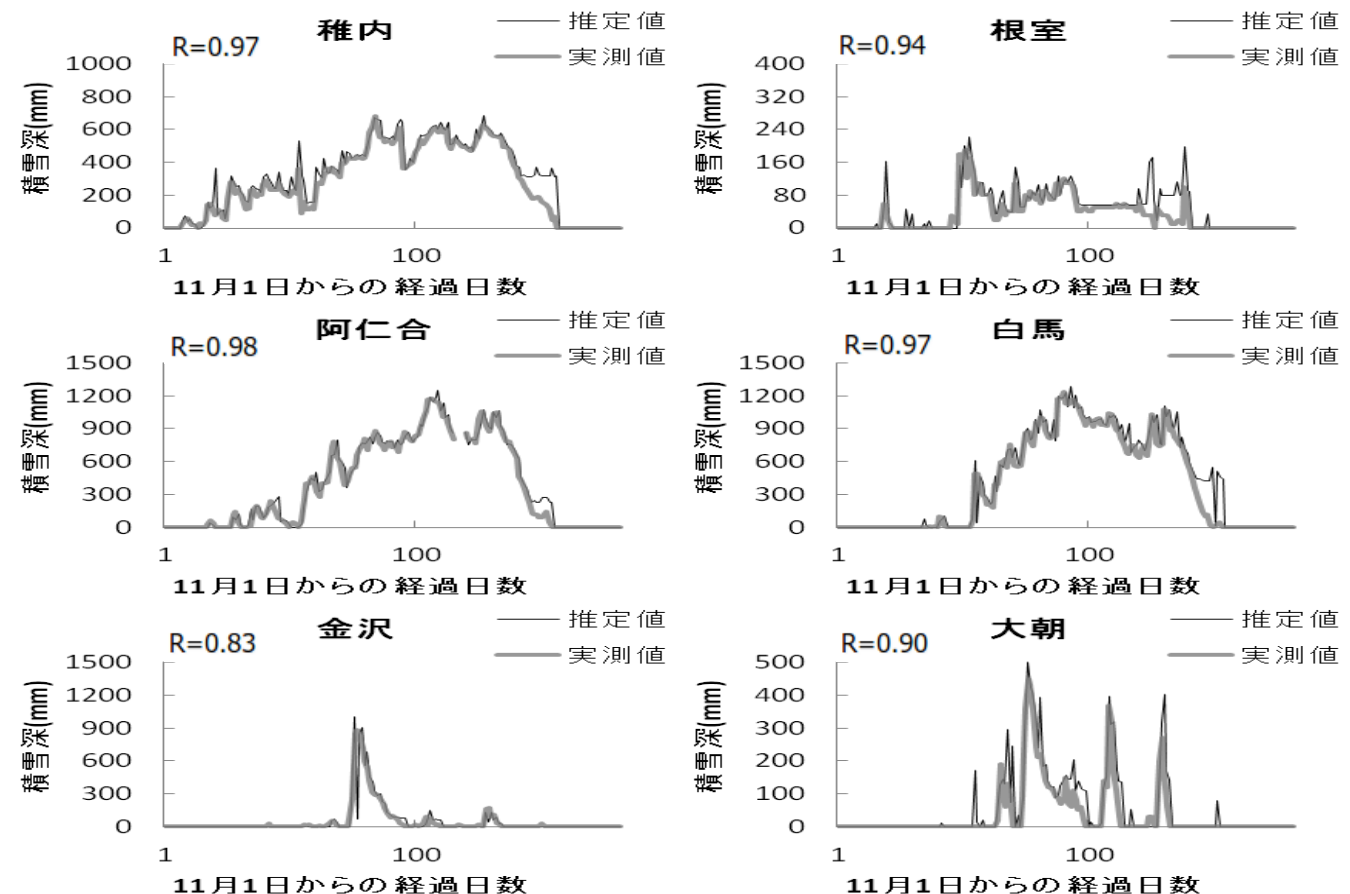

図-2 積雪深の推定値と実測値の比較（2000 年冬季）

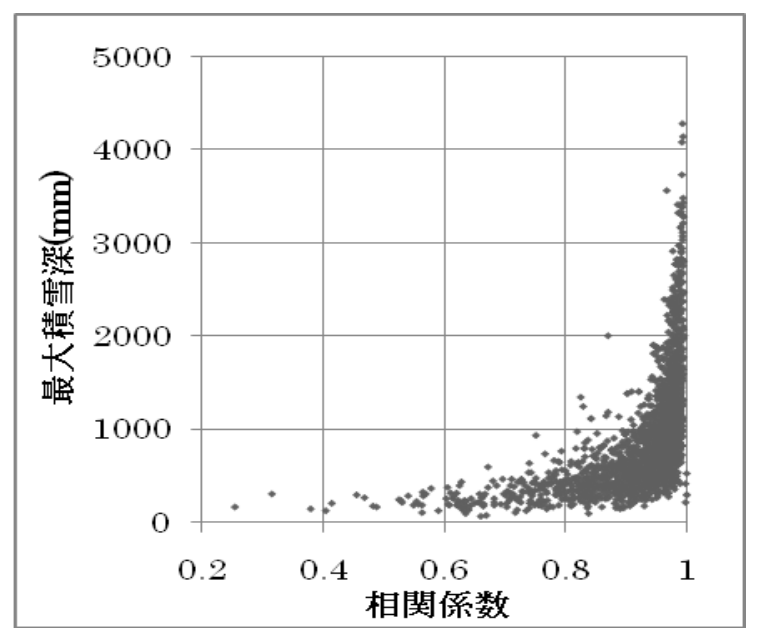

図-3 最大積雪深と相関係数の散布図

圧密速度は気温により以下のように与えた.

$$
\beta= \begin{cases}0.002 & T<1.0 \\ 0.002 T & T \geq 1.0\end{cases}
$$

また積雪深は以下のように求められる.

$$
S D=S D^{\prime}-\frac{0.284 R}{\rho d^{\prime}}\left(\frac{S D^{\prime}}{10}\right)^{10}+\frac{R}{\rho s}
$$

ここで $S D^{\prime}$ は前日の積雪深 $(\mathrm{mm}), \quad R$ は降雪量 $(\mathrm{mm})$, $\rho s$ は降雪密度 $\left(\mathrm{g} / \mathrm{cm}^{2}\right)$ である. 降雪密度は気温を用いて 以下のように与えた.

$$
\rho s= \begin{cases}0.04 & T<-2 \\ 0.0667+0.0133 T & -2 \leq T<1 \\ 0.08 & T \geq 1\end{cases}
$$

本研究の手法を用いた積雪深の再現性の例として, 2000年冬季の6観測点において最適化した融雪係数を用 いて推定した積雪深と実測值の比較を図-2に示した.

\section{Degree-Day法および融雪係数の検証結果と考察}

\section{(1) Degree-Day法の検証}

対象とした2545のケースについて融雪係数を最適化し た結果，約86\%に相当する2186のケースにおいて，積雪 深の推定值と実測值は 0.8 以上の高い相関係数を示した。 これにより，適切な融雪係数を設定すれば多くの地域に おいてDegree-Day法による融雪量の推定が有効であると いえる.

\section{(2) 相関係数と気象データの解析}

融雪係数の最適化より求めた相関係数と気象データを 解析した結果, 最大積雪深と相関係数に関係性がみられ た. 全てのケースにおける最大積雪深と相関係数の散布 図を図-3に示寸，最大積雪深の増加に伴い，相関係数は 増加する傾向にあり, 積雪量の多い地域において Degree-Day法は融雪量の推定に適していると考えられる. この結果について考察を行う. 融雪に寄与するエネル ギ一成分は日射・大気放射・顕熱伝達・水蒸気輸送に伴 う潜熱・雨による伝達熱・地中伝導熱が考えられる ${ }^{8)}$. 


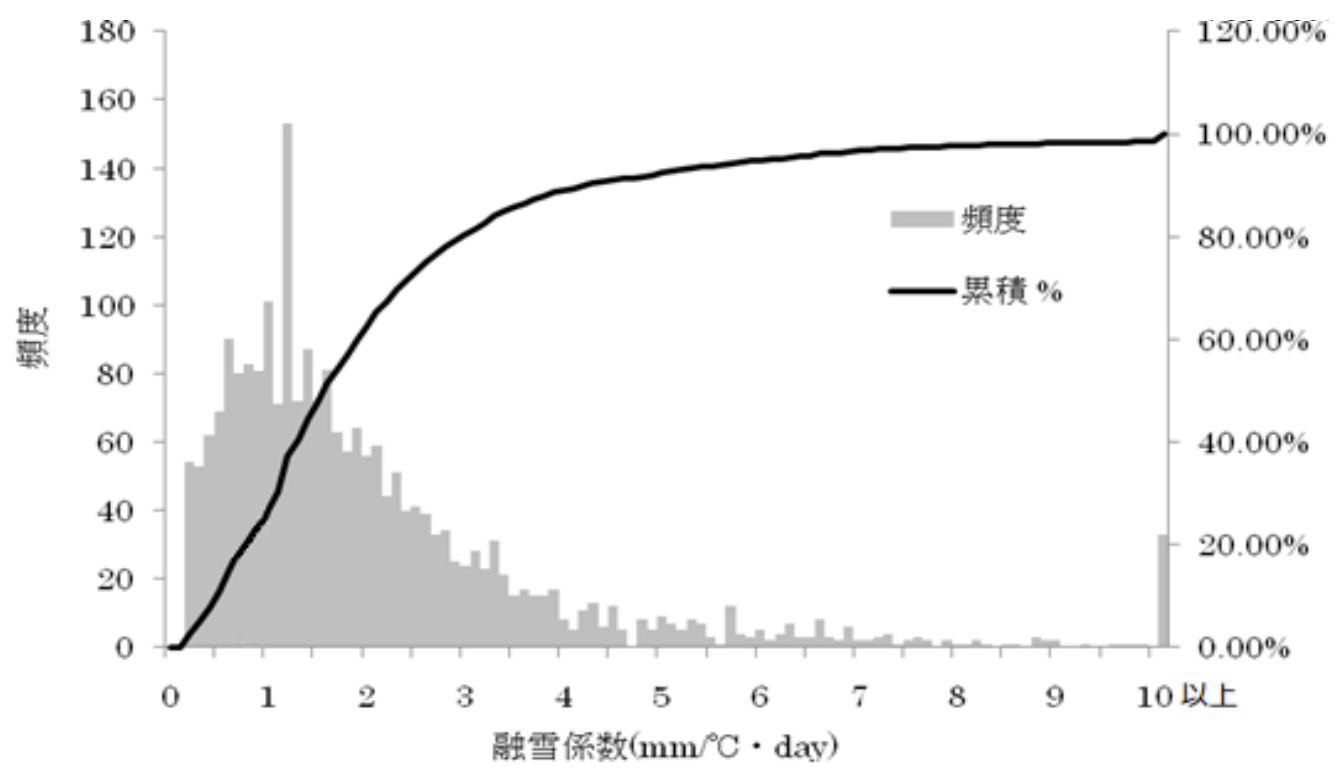

図-4 相関係数 0.8 以上のケースにおける融雪係数の度数分布

表-1 最大積雪深 $1000 \mathrm{~mm}$ 以下, 相関係数が 0.8 未満と 0.8 以上 の対象地点の気象条件

\begin{tabular}{|c|c|c|}
\hline & $\begin{array}{c}\text { 相関係数 } \\
0.8 \text { 未満 }\end{array}$ & $\begin{array}{c}\text { 相関係数 } \\
0.8 \text { 以上 }\end{array}$ \\
\hline 期間平均気温 $\left({ }^{\circ} \mathrm{C}\right)$ & 4.5 & 1.3 \\
\hline 積雪日数 $($ 日 $)$ & 54.4 & 100.1 \\
\hline 最大積雪深 $(\mathrm{mm})$ & 304.7 & 648.3 \\
\hline
\end{tabular}

表-2 融雪係数が5.0以上のグループと5.0未満のグループの 気象条件

\begin{tabular}{|c|c|c|}
\hline & $\begin{array}{c}\text { 融雪係数 } \\
5.0 \text { 以上 }\end{array}$ & $\begin{array}{c}\text { 融雪係数 } \\
5.0 \text { 未満 }\end{array}$ \\
\hline $\begin{array}{c}\text { 融雪係数 } \\
\left(\mathrm{mm} /{ }^{\circ} \mathrm{C} \cdot \text { day }\right)\end{array}$ & 8.0 & 1.7 \\
\hline $\begin{array}{c}\text { 最大積雪深 } \\
(\mathrm{mm})\end{array}$ & 325 & 474 \\
\hline $\begin{array}{c}\text { 積雪期間の } \\
\text { 日平均気温 }\left({ }^{\circ} \mathrm{C}\right)\end{array}$ & -0.3 & 0.9 \\
\hline $\begin{array}{c}\text { 融雪期間の } \\
\text { 日平均気温 }\left({ }^{\circ} \mathrm{C}\right)\end{array}$ & 1.6 & 2.6 \\
\hline
\end{tabular}

表-3 地域別のケース数に対する融雪係数が 5.0 以上の地域別ケース数の割合

\begin{tabular}{|c|c|}
\hline 地域区分 & 割合 $(\%)$ \\
\hline 北海道北西部 & 5.6 \\
\hline 北海道南東部 & 16.7 \\
\hline 東北 & 3.4 \\
\hline 北陸 & 12.4 \\
\hline その他 & 4.5 \\
\hline
\end{tabular}

これらのエネルギ一成分のうち卓越するものは日射・顕 熱伝達であるが，気温が高い場合には日射・顕熱伝達に
よる熱は気温と相関関係を持つため9)，気温が高い状態 において気温と融雪量の一次近似は成立しやすい ${ }^{10)}$.さ らに積雪量の多い地域では気温が高く一次近似できる状 態が全体の融雪期間に対して占める割合が大きい. 以上 より積雪量の多い地域においてDegree-Day法の精度がよ いと考えられる.

また最大積雪深が小さくなるに従い，相関係数は減少 する傾向にある．図-3に示すように，相関係数が 0.8 未満 である359のケースは全て最大積雪深が1000mm以下で あった．そこで最大積雪深が $1000 \mathrm{~mm}$ 以下のケースを相 関係数が 0.8 未満のグループと 0.8 以上のグループに分類 し, 気象データの平均值を比較した. その結果，表-1に 示されるように最大積雪深が $1000 \mathrm{~mm}$ 以下であり相関係 数が小さいケースは気温が高く積雪日数が少ない.また 最大積雪深が $1000 \mathrm{~mm}$ 以下であるものの相関係数が大き いケースは気温が低く積雪日数が多い. 以上より，最大 積雪深が小さくかつ気温が高く積雪日数が少ない地域に おいて，Degree-Day法による融雪量の推定は不適切であ ることが示唆された.

この結果について考察する，表面融雪が発生すると水 みちが形成され，〈ぼみが生じることがある ${ }^{11)}$. 積雪深 の小さな観測点では積雪が不均一に存在するため, 均一 な積雪面の熱収支を仮定することが難しく，また裸地に おける地表面の熱収支の影響を受けやすくなる。また， 積雪深が小さい場合には，AMeDASの積雪深観測の誤差 が積雪深に占める割合が大きくなる，以上より気温が高 く最大積雪深が小さい場合にはDegree-Day法の適用性に 問題があると考えられる。

\section{(3) 融雪係数亡気象データの解析}

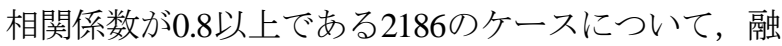




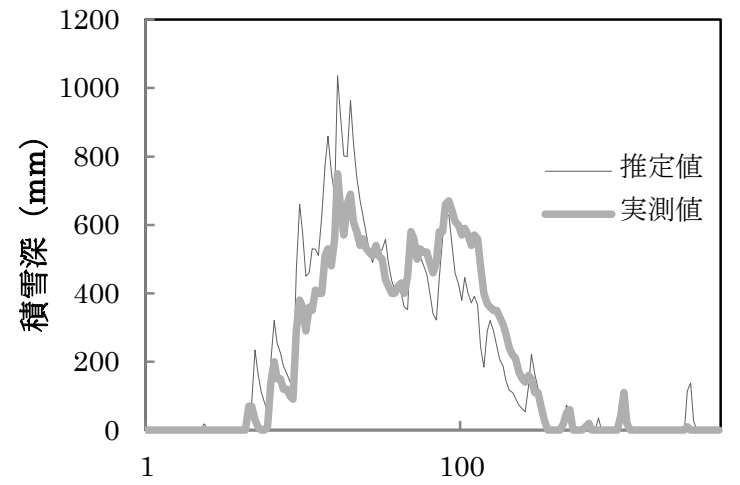

11月1日からの経過日数（山形）

図-5 熱収支法を用いた積雪モデルによる 積雪深の推定値と実測値の比較

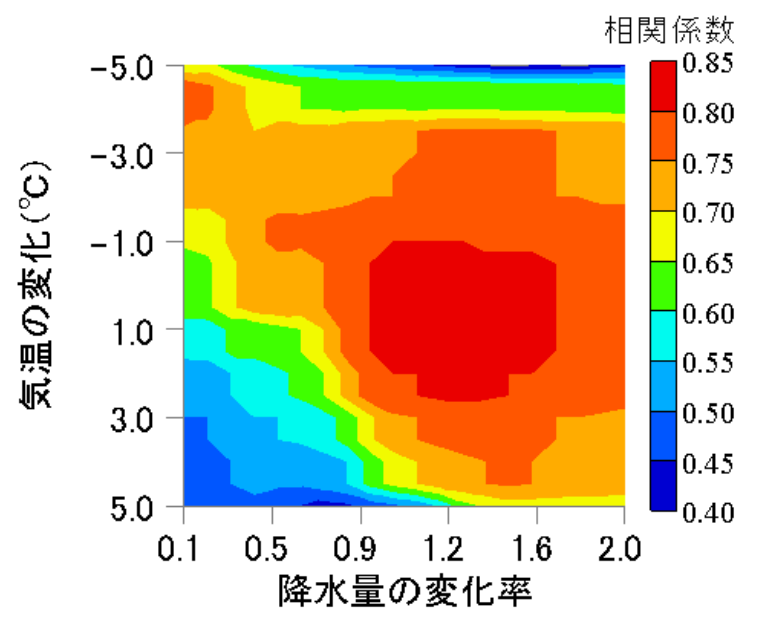

図-6 気温と降水量の変化に対する相関係数の分布

雪係数の頻度分布および累積頻度分布を図-4に示す．図 より融雪係数の值は0.1から5.0の範囲に $92.8 \%$ が分布して いることが示された. そこで融雪係数が5.0以上である 166ケースのグループと，融雪係数が5.0未満である 2020 のケースのグループに分類し, 解析を行った.

まず, 二つのグループについて, 気象データの各要素 の平均值を求めて比較した（表-2）。その結果, 融雪係 数が5.0以上であるグループは融雪係数が 5.0 未満である グループに比べ，最大積雪深が小さく，積雪期間および 融雪期間の日平均気温が低いことが示された。 これより， 最大積雪深と気温は融雪係数の值に影響を与えると思わ れる.これは，塞雪寒冷地带では降雪量や積雪量が少な $<$, 融雪が低温状態のまま進行し, 早期に消雪し, 融雪 熱量に対して放射成分が卓越するため気温のみで融雪現 象を表現することに無理があるため融雪係数が高い值に なるとした報告 ${ }^{12)}$ と一致している.

次に, 地域別のケース数に対する融雪係数が5.0以上 の地域別ケース数の割合を表-3に示す.ただし北海道地 方については, 宗谷・上川・留萌・石狩・空知・渡島・ 檜山の各振興局の管轄地域を北海道北西部とし, それ以 外の地域を北海道南東部として, 二つの地域に分けた. これより, 北海道地方を対象とした場合には, ケース数
は積雪量の多い北西部よりも積雪量の少ない南東部に多 くみられることが確認できる. 北海道南東部は北海道北 西部と比較して, 最大積雪深が少なく, 消雪日が早い時 期に訪れるとされる ${ }^{12)}$. また泠帯に属する北海道南東部 は気温が低い地域である. よって 北海道南東部は融雪 係数が比較的大きくなると考えられ，上述した解析結果 との整合性がみられた．また表-3より北陸地方は割合が 高いことが分かる．これは北陸地方には最大積雪深が小 さく積雪日数が少ないAMeDAS観測点が比較的多く存在 するためと考えられる.

\section{5. 熱収支モデルによる感度分析}

前章2節において, Degree-Day法の適用性に影響を与 える要素として最大積雪深と積雪日数, 気温を示したが, その影響を定量的に評価するためにDegree-Day法の感度 分析を行った.

\section{(1) 感度分析の方法}

Degree-Day法の適用性に影響を与える要素のうち， 最大積雪深と積雪日数は降水量と正の相関があると思わ れる. そこで降水量と気温の二つのパラメータを変動さ せた際の積雪深を, 熱収支法を用いた積雪モデルによっ て再現する. そして再現した積雪深とDegree-Dayを用い た積雪モデルにより推定した積雪深について融雪係数の 最適化を行い, 相関係数を求めた.

\section{（2）熱収支モデル}

熱収支法を用いた積雪モデルを構築するために，泉ら ${ }^{13)}$ から熱収支解析による融雪モデルを得た．この融雪モ デルは積雪を一つの層とみなし，積雪面における放射量 と潜熱・顕熱交換量より融雪熱量を求め, 融雪量を推定 する. これより, 式(2)に示寸積雪水量を推定し, 全層積 雪密度モデルと組み合わせることにより熱収支法を用い た積雪モデルを構築した。

この積雪モデルのデータセットとして, 山形の地上気 象観測所における2005年11月から翌年4月までの気象 データを気象庁月報より取得した。この期間における， 熱収支法を用いた積雪モデルによる積雪深の推定值と実 測值の比較を図-5に示す. 推定值と実測值の相関係数は 約0.89となり，熱収支法を用いた積雪モデルは積雪深を 精度よく再現することが示された.

\section{(3) 感度分析の結果と考察}

降水量はデータセットの観測值に0.1倍から2.0倍まで の降水量の変化率を掛けることにより変動させた．また， 気温はデータセットの観測值に $-5.0^{\circ} \mathrm{C}$ から $+5.0^{\circ} \mathrm{C}$ まで 
の気温の変化 $\left({ }^{\circ} \mathrm{C}\right)$ の值を加えることにより変動させた. 図-6に気温と降水量の変化に対する相関係数の分布を示 す.罒によると，気温の増加と降水量の減少に伴い相関 係数は減少している. これより気温が高く積雪量が少な い気候においてDegree-Day法の精度が低下することが示 唆された。これは最大積雪深が小さくかつ気温が高く積 雪日数が少ない地域において，Degree-Day法による融雪 量の推定は不適切であるとした前章2節の検証結果と一 致している.この結果を気温と降水量を用いて定量的に 評価すると, 相関係数が 0.7 以上なる条件として式(7) が得られた。

$$
Y-5.8 X \geq-2.0
$$

ここで降水量の変化率の值を $X$, 気温の変化量 $\left({ }^{\circ} \mathrm{C}\right)$ の值 を $Y$ とした.

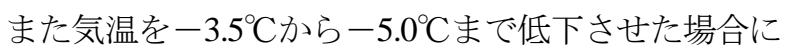
相関係数の減少がみられ，そのケースにおいて最適化さ れた融雪係数は $20 \mathrm{~mm} / \mathrm{day} \cdot{ }^{\circ} \mathrm{C}$ 近い值であった. これより 気温が著しく低い気候では融雪係数が増加することを示 唆された. これは冬季の日平均気温が低い地域において, 融雪現象を気温のみで表現することに無理があるため融 雪係数が増加する前章3節の検証結果と一致している.

今後様々な気候の地域で感度分析を行うことにより，

Degree-Day法のパラメータ補正法を定式化することが望 まれる，ただし熱収支法を用いた積雪モデルには多様な 気象データが必要であり, 気象観測所の観測精度が分析 結果に影響を与えやすいことに留意する必要がある.

\section{6. おわりに}

本研究では，日本全域のAMeDAS観測点において融雪 係数を求め, Degree-Day法の精度や融雪係数について検 証を行った. その結果を以下に示す.

・全国の約 $86 \%$ の地点においてDegree-Day法により融雪 量を精度よく推定できた。

・気温が高い状態で融雪が進むため, 積雪量の多い地域 においてDegree-Day法は融雪量の推定に適している.

・最大積雪深が小さく，かつ気温が高く積雪日数が少な い地域においてDegree-Day法は融雪量の推定に不適切で ある.

・融雪係数が比較的大きくなる事例は北海道南東部にお いて多くみられ, 融雪係数の増加に影響する気象要因と して，最大積雪深と気温を確認することができた.

・熱収支法を用いた分析により，気温と降水量が Degree-Day法の適用性に影響を与えることを確認し，そ の影響を式(7)により定量的に評価した.

これらの知見はDegree-Day法が使用可能な地域の判別 方法の確立や，日本全域の積雪量データベースの作成に 役立つと思われる.
謝辞 : 本研究の一部は, JST/JICA地球規模課題対応国際 科学技術協力事業(SATREPS)の援助によるGRANDEに よって実施されました。

\section{参考文献}

1) 本谷研: 東北地方における積雪水量の 27 年平均值と豪 雪・塞雪, 雪水, 70巻3号, pp.561-570,2008.

2) So Kazama, Hirokazu Izumi, Priyantha Ranjan Sarukkalige, Takayuki Nasu, Masaki Sawamoto.: Estimating snow distribution over a large area and its application for water resources, Hydrological Processes, 22(13), pp.2315-2324, 2008.

3) Kominami, Y., Tanaka, N., Endo, Y. and Niwano, S.: Estimation of snow distribution under global warmingusing data from remote weather stations (AMeDAS), .Journal of Agricultural Meteorology, 60, pp.445-450, 2005.

4)山崎剛: 融雪係数の熱収支的検討, 雪水, 57 巻 3 号, pp.239-244, 1995.

5) 板倉忠興 : 水理公式集, 社団法人士木学会, p.27, 1949.

6) 泉宏和, 風間聡, 戸塚岳大, 沢本正樹 : 全日本の積雪水 量, 積雪深, 全層積雪密度分布推定, 水工学論文集, 第 49巻, pp.301-306, 2005.

7) 風間聡 : 広域における積雪全層密度推定に関する研究, 水工論文集, 第41巻, pp.245-250, 1997.

8）小野延雄, 石川信敬, 新井正, 若土正僥, 青田昌秋: 雪 水水文現象, 古今書院, pp.18-19, 1994.

9) 小島賢治：融雪機構と熱収支, 気象研究ノート, 第136 号, pp.1-38, 1979.

10）熊倉俊郎, 山野井克己, 早川典生 : 積雪の多層圧密モデ ルを用いた北陸地方の降積雪現象の解析, 雪水, 66 巻1 号, pp.35-50,2008.

11) Kathy L.Young, Jane Assini, Anna Abnizova and Nelson De Miranda : Hydrology of Hillslope-Wetland Streams, Polar Bear Pass, Nunavut, Canada, Hydrol. Process. 24, pp.33453358,2010 .

12) 朝岡良浩, 小南裕志, 竹内由香里, 大丸裕武, 田中信 行 : 衛星観測に基づく積雪水量の広域推定と融雪係数の 地域性，水文・水資源学会誌，第20巻，第6号， pp.519$529,2007$.

13）泉宏和，風間聡，沢本正樹 : 積雪水資源量評価における 森林の影響について, 水工学論文集, 第50巻, pp.421-426, 2006.

(2011. 9. 30受付) 